\title{
SEISMIC RESPONSE AND FAILURE ANALYSES OF A MIXED-OXIDE FUEL FABRICATION PLANT
}

\author{
F. J. Tokarz \\ R. C. Murray \\ H. C. Sorenzen
}

February 14, 1975

Prepared for U.S. Energy Research \& Development Administration under contract $N$ 3. W-7405-Eng-48

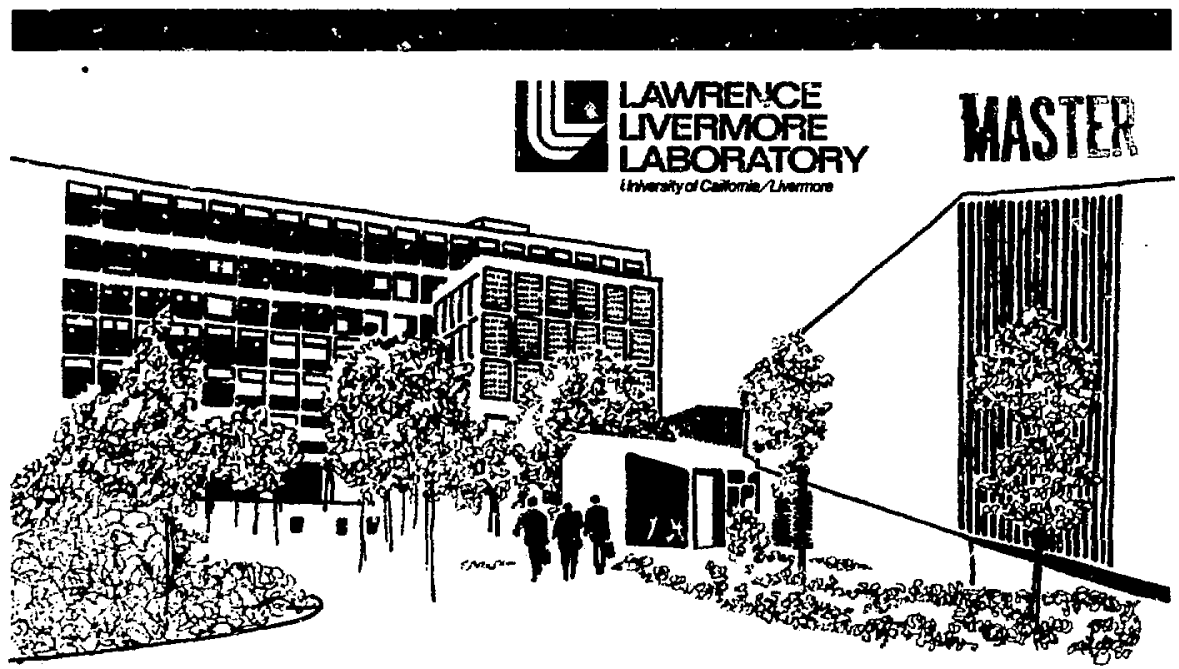




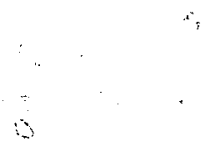

NOTICE

"This report was prepared as an account of work sponeored by the United States Government. Neither the United States nor the United States Eneszy Reserrch \& Development Adminintration, nor 8 .. of their enployecs, nor any of their contructors, subcontrnctors, or their employees, mukec any warrenty, express or Implied, or asumei any lejal liability or restorsibility for the mesurscy. conopleteness or urefuiness of any information, apperatus, product or prociess disclosed, of repienients shat its we would not infinge pivite y-awned rights."

$-$

Printed in the United States of America Available from

National Technical Information Service

U.S. Department of Commerce 5285 Port Royal Road

Springfield, Virginia 22151

Price: Printed Copy $\$$; Microfiche $\$ 2.25$

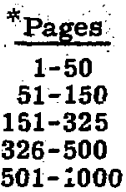

NTIS

Selling Price

$\$ 4,00$

$\$ 5.45$

$\$ 7.60$

$\$ 10.60$

501-\$000

$\$ 13.60$ 
TID- $4500, \mathrm{LC}-38$

Engineering and Equipment

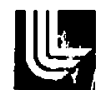

\title{
LAWFENCE LNERMORIE LAEORATORY

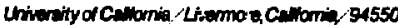

LCRL-51755

\section{SEISMIC RESPONSE AND FAILURE ANALYSES OF A MIXED-OXIDE FUEL FABRICATION PLANT}

\author{
F. J. Tokarz \\ R. C. Murray \\ H. C. Sorensen
}

MS, date: February 14, 1975

\begin{abstract}
This repart methork
oponsored by the Prepared as an eccount of rotr

the Untited State Uniled Statea Goverent of work

Rewereh

thetres and Derelopment Adminitration, Enerty

nubcontmployes, not any of their con any of

wocontuctors, or their of their contractors

wirnaty, exprese or imoli employeca, makes any

Mability or repon or impled, of alsumes eny any

or usefulnets of ing inty for the accuracy, complest

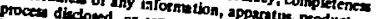

infly dieclowed, or tepresents thit its

chestely owned riphts.
\end{abstract}




\section{Contents}

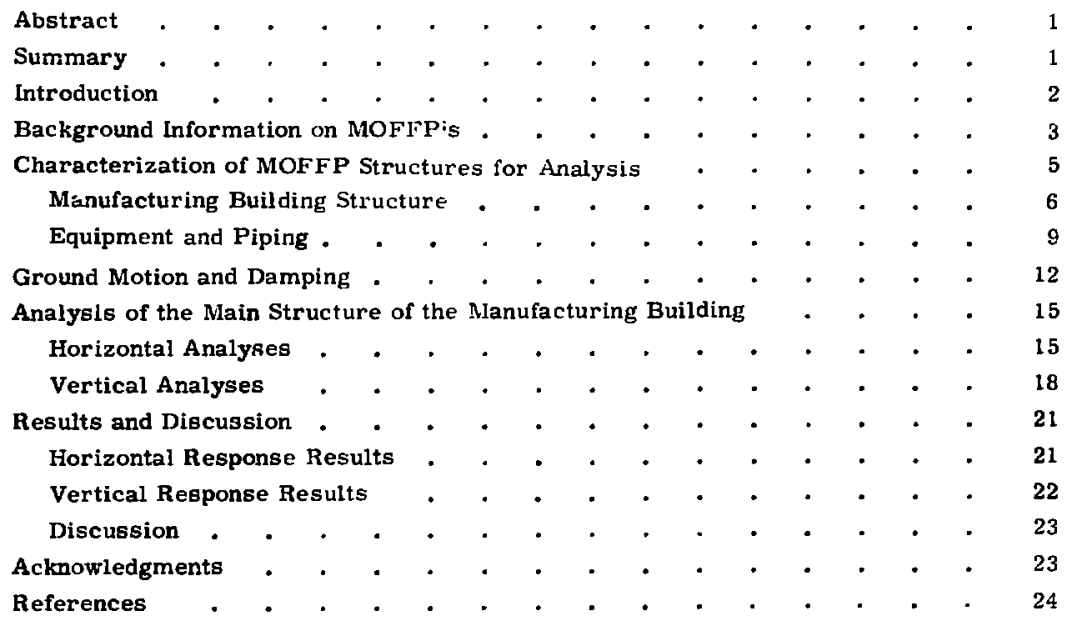




\section{SEISMIC RESPONSE AND FAIIURE ANALYSES OF A MIXED-OXIDE FUUL FABRICATION PLANT}

\section{Abstract}

We studied the structural integrity and possible failure modes of mixed-oxide fuel fabrication plants (MOFFP) subjected to different ground-motion intensities ranging from 0.1 - to $1.0-\mathrm{g}$ peak accelerations. To perform this study, we developed calculation models of safety-related systems to be used in the analysis. We performed both elastic and inelastic dynamic response analyses for both horizontal and vertical ground motion. Our conclusions regarding the structural integrity for the model MOFFP are as follows: 1) no structural damage at ground motions $<0.4 \mathrm{~g} ; 2$ ) severe structural damage at 0.4 to $0.5 \mathrm{~g}$; 3) complete building collapse at $>0.5 \mathrm{~g}$; 4) building collapse before equipment failure.

\section{Summary}

We performed a study to evaluate the structural integrity and possible failure modes of mixed-oxide fuel fabrication plants (MOF FP) subjected to various ground-tnotion intensities ranging from 0.1 - to $1.0-\mathrm{g}$ peak ground accelerations. Because of the presence of plutonium oxide and uranium oxide at these plants, this information is needed to provide a technical basis for information included in the U.S. Nuclear Regulatory Commission assessment of the environmental impact and public risk associated with siting MOFFP's.

A significant portion of the study invol ved the development of calculational models of safety-related systems to be used $i$ in the analysis, with primary emphasis on the main structural systems of the manufacturing building. These safety-related sy .tems include both glove boxes and barriers, the $\mathrm{PuO}_{2}$ storage bins, final HEPA filter frames, ducting, and utility piping. These systems comprise the confinement system that limits a potential release of plutonium oxide.

The MOFFP used in our calculations was carefully designed to model a "representative" facility. It is expected that most future MOFFP's will be located east of the Continental Divide near reprocessing plants and power reactors. In that region, tornado rather than earthquake criteria will generally govern the external structural design while seismic criteria will influence the design of internal equipment and piping. The design earthquake ground-motion levels would be in the 0.1- to 0.2-g range.

We performeo both elastic and melastic dynamic response analyses on the main structure. Ground motion used for input was based on AEC Regulatory Guide $\mathbf{1 . 6 0}$ (Ref. 1). Lamping values used were 
consistent with AEC Regulatory Guide 1.61 (Ref. 2). Both horizontal and vertical response analysis were conducted, with each treated separately.

The results of our horizontal inelastic response analyses for MOFFP's founded on hard sites (shear velocity of 8000 fps) show that below $0.6-\mathrm{g}$ maximum horizontal ground acceleration, th 2 main building shows no appreciable damage (i.e., no extens ive cracking). At $0.8 \mathrm{~g}$ and greater, the total lateral resisting capacity of the building is exceeded and the building collapses. For MOFFP's on interm ediate (shear velocity of 2000 fps) or soft (shear velocity of $500 \mathrm{fps}$ ) sites, extrapolation from the elastic response analysis including soil-structure interaction effects shows that total building collapse from lateral motions occurs in the 0.5- to $0.6-\mathrm{g}$ range of ground acceleration.

Analysis of vertical motions shows that roof slab damage occurs at about $0.4 \mathrm{~g}$; the floor slab and most of the roof slab show plastic deformation at 0.5 to $0.55 \mathrm{~g}$; and total collapse occurs above $0.55 \mathrm{~g}$.

The conclusions segarding the structural integrity for the model MOFFP we developed are summarized below:

- No structural damage at ground mctions $<0.4 \mathrm{~g}$.

- Severe structural damage at 0.4 to $0.5 \mathrm{~g}$.

- Complete building collapse at $>0.5 \mathrm{~g}$.
With minimal structural modifications, such as additionai reinforcing steel in the walls, the building modeled for our study could be made capable of carrying ground motion levels exceeding $1 \mathrm{~g}$.

Review of representative equipment located within the manufacturing building indicates that by proper design the equipment will have a natural frequency $>30 \mathrm{~Hz}$. The maximum acceleration the equipment will experience will then be the maximum floor acceleration. Input motion to the equipment is obtained by developing instructure response spectra called floor spectra. These spectra include the effects of dynamic amplification of the ground motion by the structure.

We have generated floor spectra and moximum noor accelerations for our model building founded on a hard site. We found the maximum floor acceleration to be less than two times the maximum ground acceleration.

We have estimated the elastic strength of the equipment and found it able to survive acceleration levels greater than 1 to $2 \mathrm{~g}$ 's. Inelastic analyses of equipment would increase these levels.

At ground acceleration levels $<0.5 \mathrm{~g}$, we do not expect any equipment failures. We expect complete building collapse before equipment failure.

\section{Introduction}

This is a final report of a study by the Lawrence Livermore Laboratory that was requested and funded by the U.S. Nuclear Regulatory Commission, Office of Standards Development.

Our study identifies probable failure modes in a model of a commercial-scale
MOFFP that we subjected to various intensities of earthquake ground motion. The resulting failure modes $w$ ill be used to estimate radiation-scurce terms for earthquake-induced accidents in commercial-scale MOFFP's. 
Our study efforts included the following:

- Characterization of a model commercial-scale MOF FP to form the basis for the calculational models.

- Development of an acceleration time-history with a frequency content compatible with AEC Regulatory Guide 1.60.

- Performance ol dynamic response analysis using ground-motion intensities ranging from Modified
Mercalli VII $(0.2 \mathrm{~g})$ to $\mathrm{X}(\geq 1 \mathrm{~g})$ earthquakes.

- Identification of failure modes associated with the various levels of ground-motion intensities.

The characterization of a typical MOlFP involved a significant portion of our study. Once it was characterized, we defined the ground motion to be used in our analysis and performed dynamic response analysis of the manufacturing building.

\section{Background Information on MOFFP's}

When reactor fuel elements are spent, they are sent to a fuel reprocessing plant where plutonium and uranium are recovered for re-use. The zecovered plutonium and uranium oxides will be sent to mixed-oxide fuel labrication plants (MOFFP), where they will be made into new fuel elements for light-water-cooled reactors. The fuel cycle for light-watercooled reactors is shown in Fig. 1 (ReI, 3 ).

The MOFFP of the future 110 to $15 \mathrm{yr}$ hence) is expected to produce approximately 1 metric ton of mixed-oxide fuel per day. This fuel will contain about 2 to $4 \%$ by weight of pluionium oxide and the remainder uranium oxide. Because plutonium presents a much greater radiological hazard than uranium, our study concentrates on earthquake-induced accidents in plutonium processes.

Future MOFFP's will contain many design and operational features to avoid cricucality conditions and to influence or limit the potential release of plutonium. These include process confinement systems, control of process inventory, and building integrity. Procuss confinement includes glove boxes and associated exhaust systems in the powder steps of the process and the cladding after encapsulation of the sintered fuel pellets. Control of the fuel inventory includes separating the various steps in the process either by means of isolation (distance or barriers) or by employing parallel production lines to reduce the normal process inventory. In sone facilities, similar processes are confined in separate areas, which provide

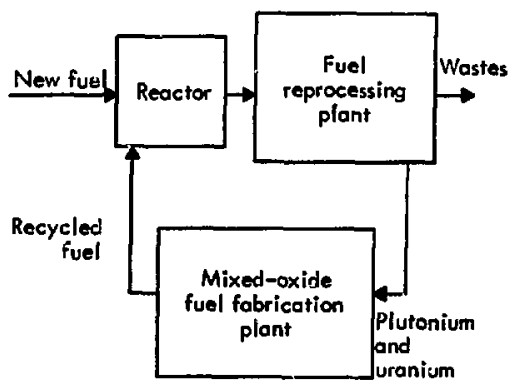

Fig. 1. Fuel cycle for light-water-cooled reactors. 
additional control against release of radioactive material.

The confinement design features are usually designated as barriers. The process confinement is called the primary barrier: the separation of the processes into separate rooms is termed a secondary barrier; and the building structure and building exhaust system are generatly called the final barrier. Plutonium and uranium oxides will enter the MOFFP manufacturing building in powder forill. The process steps in the fabrication of fuel are strown in Fig. 2. Potential inhalation hazards exist where plutonium oxide is in powder form (sleps A, B, C, $D$, and E). In step $A$, the recelving and storage area, both plutonium and uranium oxides are stored in double cosiainers. The containers are usually in racks to prevent overturning and to provide spacing to avoid criticality accidents. Step B includes the transfer systems between various stages of the process. Either manual or mechanical transportation schemes are used to move the plutoniumoxide powder.

Weighing and blending: steps $C$ and $D$, are both performed in a gloved barrier. In the remaining processes (milling, pressing, sintering, grinding, cleaning, and loading intc fuel rods), the plutonium oxide is not readily dispersible. In step E, all wastes are reprocessed by a

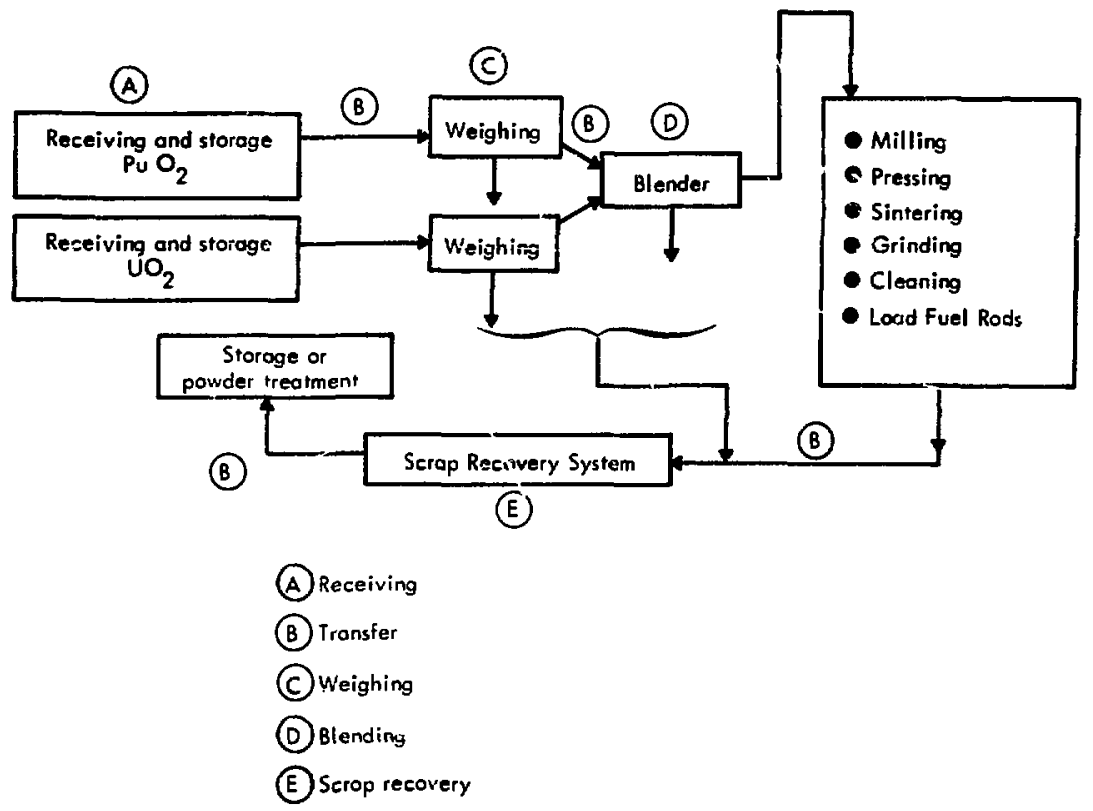

Fig. 2. Flow chart showing fuel fabrication process. 


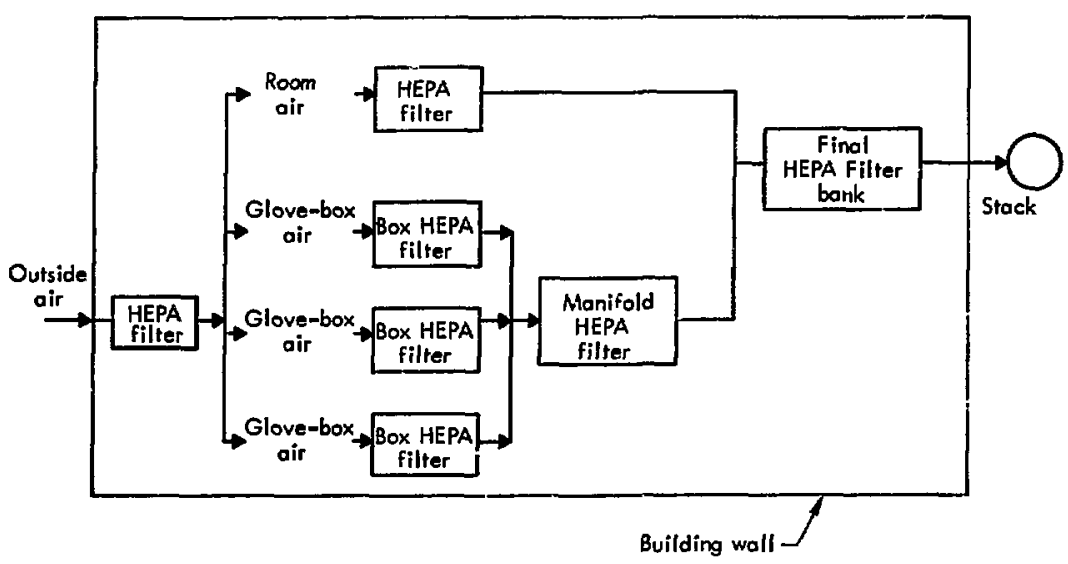

Fig. 3. Typical ventilation system.

scráp-recovery system located in glove boxes.

Figure 3 is a schematic of the ventilation system used for air cleaning in the manufacturing building. Within the manufacturing building air flow is always in the direction of greater radioactive contamination potential. The systems employ high-efficlency particulate air (HEPA) filters to minimize the release of airborne plutonium oxide from the building.
Separate HEP.A filters are provided for glove boxes, gloved barrier, and work rooms. Air is filtered when it enters the plant, when it enters glove boxes and gloved barriens, when it leaves the glove boxes and gloved barriers, when it leaves the work areas, and, firually, when it leaves the buildirg through a final HEPA filter bank. The final double-HEPA filter bank is a critical part oi the final confinement barrier.

\section{Characterization of MOFFP Structures for Analysis}

The model MOFFP that we characterize for our study must be reasonably representative of future MOFFP designs if we are to consider our results as representative. We used several sources of information for our design:

- A review of the License Application for the Westinghouse Recycle Fuels Plant to be iocated in Anderson, South Caro- lina. 4 This plant will have an annual receipt of material sufficient to produce approximately 200 metric tons/year initially, and approximately 400 metric tons/year in the future.

- Discussions with personnel from the Ralph M. Parsons Company who are currently designing the Westinghouse plant. The discussions dealt primarily 
with alternative building layouts and equipment for future plants.

- Information obtained from a visit, and discussions at the EXXCN Nuclear Plant (40 metric tons per year) in Richlisnd, Washington. Our discussion concentrated on typical equipment that might be used

- Discussione with Battelle Nortbuegl personnel. 5

\section{MANUFACTURING BUILDING STRUCTURE}

Our study emphasized an evaluation of the main structure of the manufacturing building (final confinement barrier). We also examined glove boxes and gloved Darriers (primary confinement barrier). a $\mathrm{PuO}_{2}$ storage bit, the veniiiation system dueting, the final HEPA filter bank (final confinement barrier), and utility piping.

\section{General Layout}

The manufacturing building of a future MOFFP is assumed to he a two-story structure. Figure 4 shows what we consider to be a representative layout of work areas in the building. The emergency power supply, waste-handling equipment, building exhaust system, and powder storage and scrap recovery areas are on the second floor. The first floo. (ground level) includes the emergency control room anci areas for chemical analysis, fuel fabrication, sintering furnaces, weighing, and blending. Areas where plutonium is in powder form will be enciosed by a restricted access barrier and is called the "canyon" area. The canyon area is assumed to extend from first floor to the roof.
Structural Features of Manufacturing Building

Figure 5 shows a plan and clevation that define our typical manufacturing building. The building is $210 \mathrm{ft}$ square with 18 -in.-thick reinforced eoncrete roof, noore, ant walls, 'rt.e first story extenos $20 \mathrm{ft}$ above grade, with the roof $50 \mathrm{ft}$ above grade. The structure is assumed not to extez,d below gradie.

The vertical inad-carrying system consi $i s$ of slabs spannin $n_{\ddot{c}}$ between stpporting

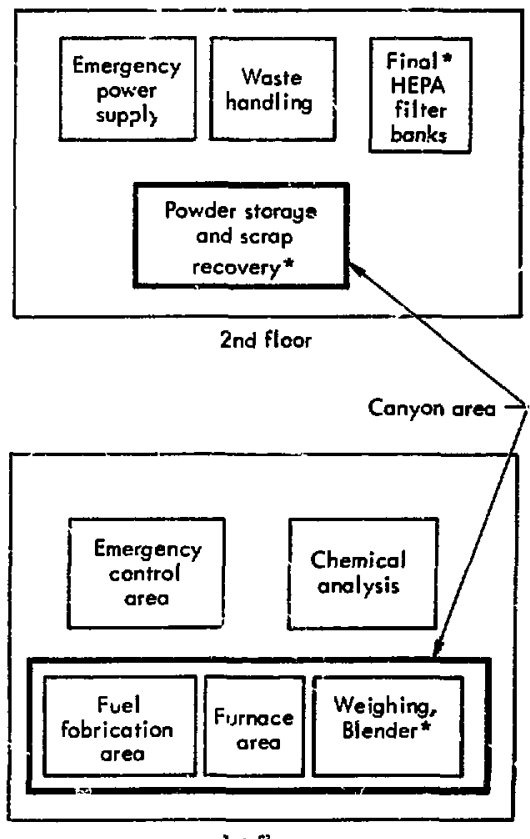

1st floor

*Areas where $\mathrm{PuO}_{2}$ can be in powder or dispersed form.

Fig. 4. Typical areas within manufacturing building. 
edge buams that bear on $24 \times 24$ in. columns on $30 \mathrm{ft}$ centers each way. At end iays, tiee exterior walls act as bedring walls. Should neavy equipment be located on the second floor, additional heams would be provided to carr: the added load.

The lateral force-resisting system consists of Moor and rouf slabs and shear walls. The slabs are assumed to act as rigid concrete beams (diaphragms) spanning between exterior shear walls that are parallel to the direction of applied forees.

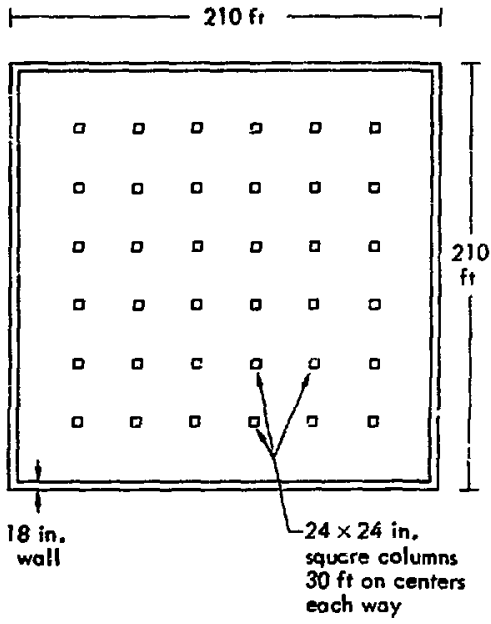

Plan view

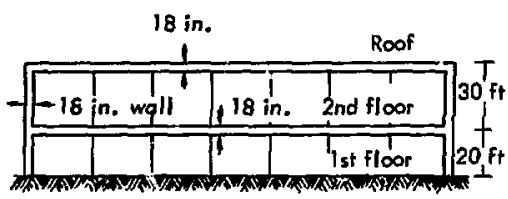

Elevation

Fig. 5. Typical manufacturing building of a MCFFP.
The shear walls transmit the loads to the fou.diation. Adequate space between the manufacturing building and adjacent struclures is assumed to accommodate differential motions.

End walls perpendicular to the direction of laterai loadings were not considered effective lateral resisting members. The interior canyon walls were treated as partition walls and were not considered part of either the vertical or ateral forceresisting systeme. The interior columns were also assumed to jâve no lateral loadresisting capecity.

Design Basis of Manufacturing Building

Nost MOFFP's (perhaps as many as $90 \%$ ) expected to be built in the next $30 \mathrm{yr}$ will be located east of the Continental Divide near fuel reprocessing plants and nuclear power reactors (typically neor electrical load centers). This would result in tyoica! MOFFP manutacturing building external structural desigcs being governed by Region I tornado criteria. Figure 6 shows the different tornado intensity regions across the countr: as specified for power reactors by the Directorate of Regulatory Standards. The variation in design basis characteristics is governed by the maximum wind speed and atmospheric pressure change associated with the differant regions, U.S. AEC Regulatory Guide 1.76 and ANSI A58,1-1972 (Refs, b and 7) define the tornado design loading. Otr representative manufacturing buildıng external structural design was governed by these criteria.

Both the roof and alls are designed for 500-psf tornado loading. The root is 
considered as a slab that distributes the load in both horizontal directions, while the walls are treated as slabs that distribute the load between the floor and/or roof levels. Horizontal steel in the walis is the minimum required for shrinkage and temperature considerations. The floor and columns are designed for $400 \mathrm{psf}$ floor loading ( 175 psf live and $225 \mathrm{psf}$ dead load). The floor is considered a two-way slab and the columns as doublyreinforced tied members. Ultimate strength design concepts ${ }^{8}$ are employed throughout, assuming 3000 psi concr te and reinforcing steel with minimum yield strength of $4 \mathrm{C}, 0 \mathrm{CO}$ psi. Figure 7 shows the reinforcing details. Design of the floors and columns will be governed by seismic criteria. An 18-in. floor slab appears to be a reasonable thickness to minimize seismic loads to equipment.

Seismic considerations played no part in arriving at our final MOFFP manufacturing building external structural design. Seismic criteria in Region I give peakdesign ground motion levels in the $0.1-$ to $0.2-g$ range. so tornado design criteria are overriding. In Regions II and III, however, the tornado loading decreases by a factor of about 2 over Region I, while the seismic loads approach the 0.5- to 0.6-g level. This change in loading means that seismic criteria will usually control the external structural design in Regions Il and III. MOFFP's built in the se regions will be considered on a case-by case basis.

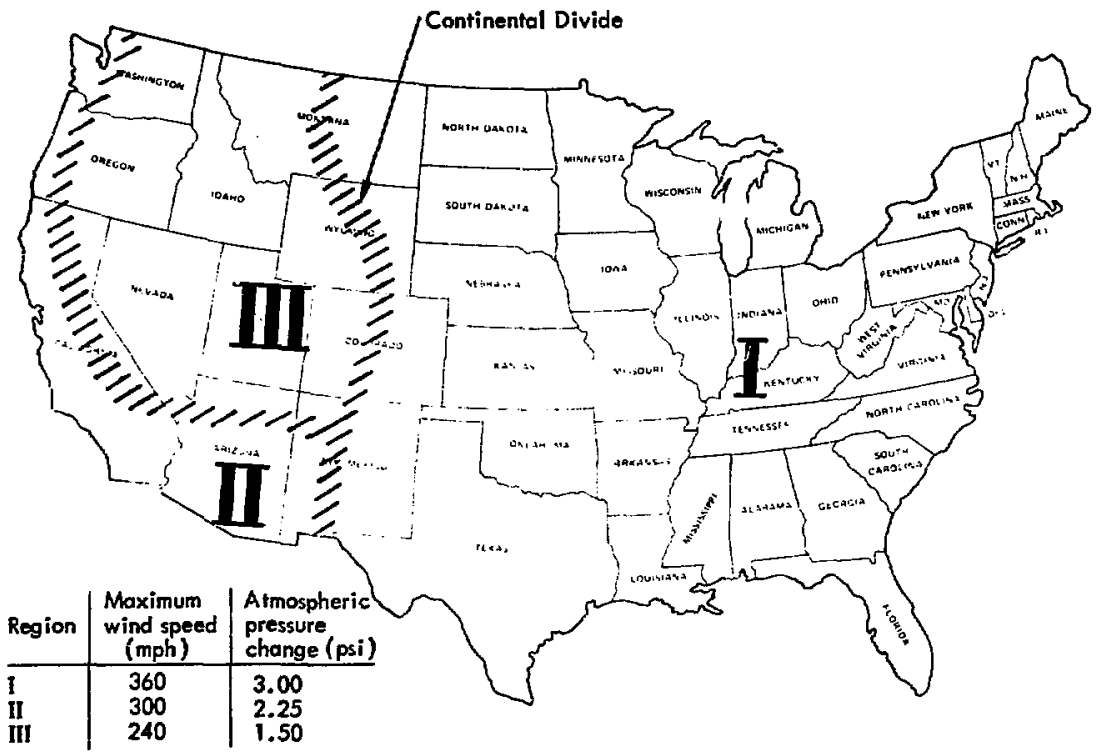

Fig. 6. Tornado intensity regions. Source: U.S. AEC Regulatory Guide 1.76 (1974). 


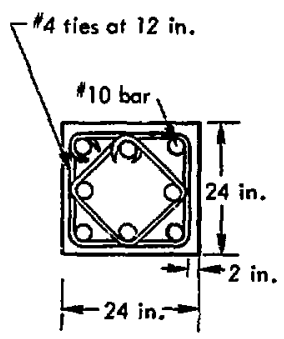

Column reinforcing

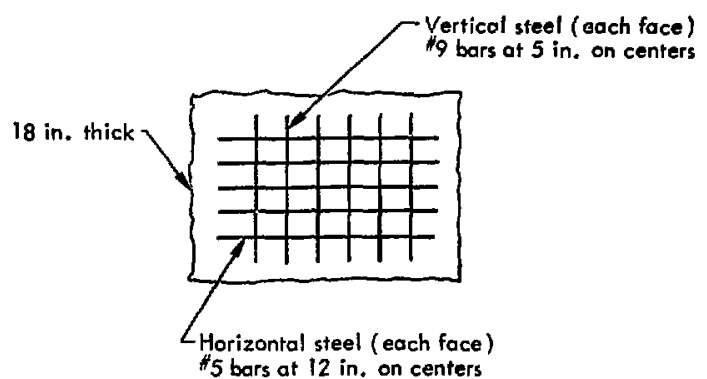

Wall reinforcing

" 8 bars of 12 in, on centers;

both horizontal direcrions and top and bottom.

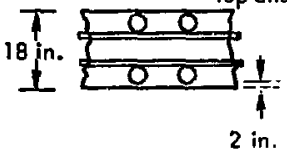

Floors and roof reinforcing

Fig. 7. Reinforcing detalls of walls, roofs, floor, and columns.

\section{EQUIPMENT AND PIPING}

Revtew of representative equipment located within the manufacturing building indicates that by proper design and location of attachments, the equipment will have a natural frequency $>30 \mathrm{~Hz}$. The maximum acceleration the equipment will experience will then be the maximum floor acceleration. Input motion to the equipment is obtained by developing floor spectra. These spectra include the effects of dynamic amplification of the ground motion by the structure.

We have generated floor spectra and maximum floor accelerations for our model building founded on a hard site. We found the maximum floor acceleration to be less than two times the maximum ground acceleration.

This section includes our estimates of the elastic strength of the equipment.

Glove Boxes and Gloved Barriers

All processes and operations thai involve quantities of plutonium oxide in powder form sufficient to cause potential inhalation hazard are performed in glove boxes or gloved barriers. These processes include weighing, blending, milling/pellet pressing, and scrap recovery. The glove boxes are used for the process confinement of weighing and scrap recovery operations. The blending and milling/pellet pressing operations are performed in gloved barriers. 
Both the giove boxes and gloved barriers are assumed located within a restricted access area. This access area is part of the caryon construction enclosing the main fabrication, powder storage, and scrap recovery areas. The canyon area is assumed to be constructed of 8-in. concrete block walls spanning between pilasters $10 \mathrm{ft}$ apart. All concrete block cells are assumed filled with grout, and reinforcement is assumed in the horizontal and vertical directions.

Figure 8 shows what we considered a representative glove box design. The glove box is constructed of 12-gage stainless steel with a $3 / 8-i n$, shatter-proof glass window. It is $30 \times 42 \times 96$ in, and weighs $5000 \mathrm{lb}$ with the process equipment. The glove box is fastened to a structural steel support frame that is anchored to the floor of the main building structure.

The gloved barrier (Fig. 9) is made of 10-in, thick reinforced concrete. It extends from first noor level to the second foor and is about $5.5 \times 8.5 \mathrm{ft}$.

Experience at LLL indicates that the glove boxes and gloved barriers can withstand noor acceler ation levels greater than I $g$.

In examination of possible penetration of the stainless steel portion of the glove box because of concrete spalling or falling objects, such as piping, was conducted. Results indicate objects greater than $100 \mathrm{lb}$ are needed for penetration. Objects of this size (concrete chunks) are not available prior to total collapse of the main building.

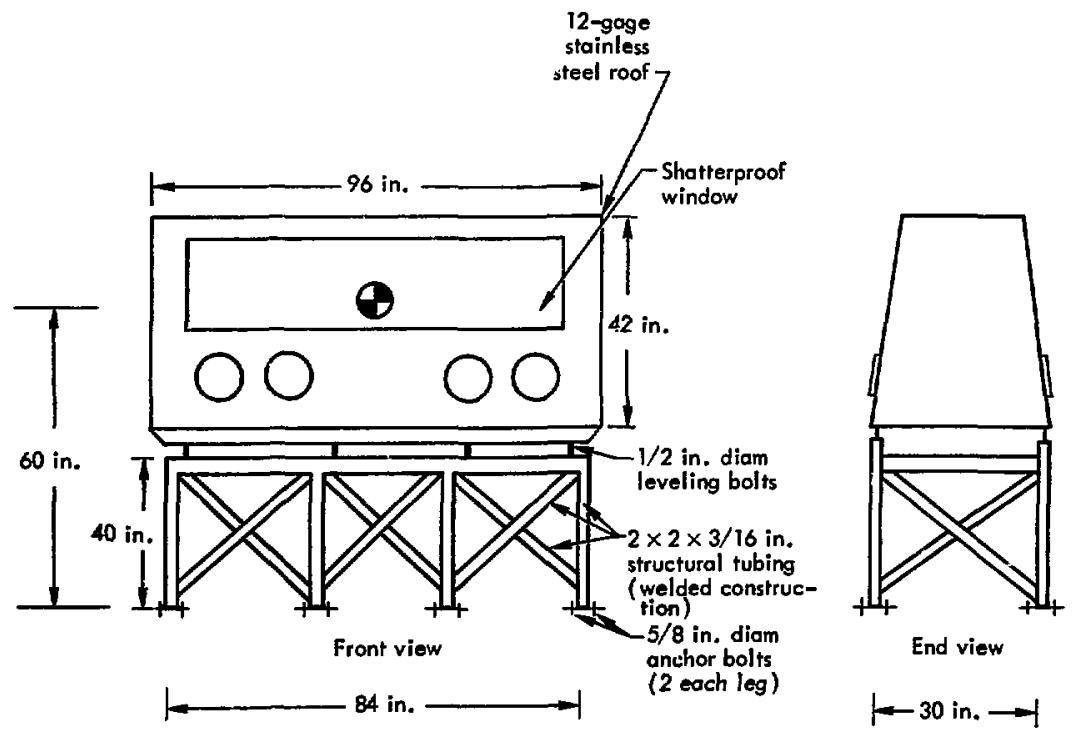

Fig. 8. Typical glove box design (weight about 5000 lb). 


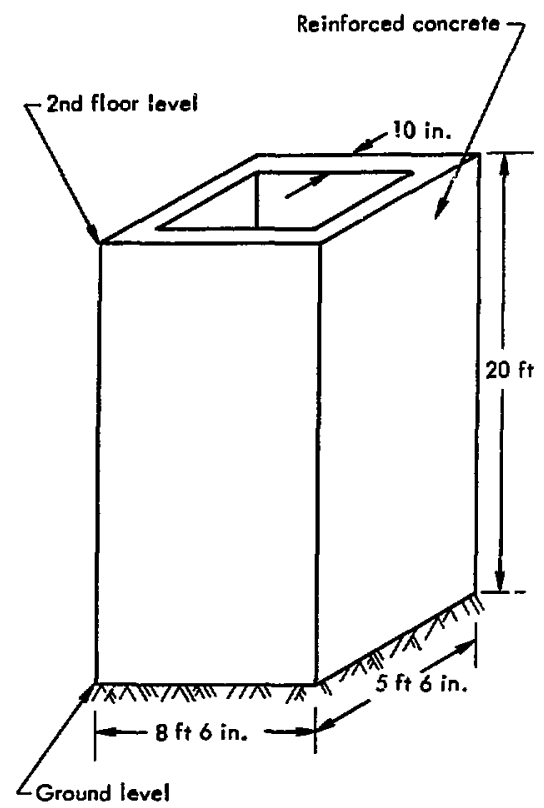

Fig. 9. Representative gloved barrier for blender.

\section{$\underline{\mathrm{PuO}}_{2}$ Storage Bins}

$\mathrm{PuO}_{2}$ powder is stored in bins prior to weighing and blending. These bins must be designed to receive powder from the transfer system, avoid criticality conditions, and inventory the powder by weighing. Weighing may be accomplished by picking up the bin. A representative storage bin is shown in Fig. 10. We have chosen to support the bin by two seats and have provided four braces for lateral support as shown. The weight of the bin and powder has been er : : id to be $1500 \mathrm{lb}$. The integrity of the bin to seismic motions will be governed by the adequacy of the support. Estimates of eupport requirements indicates that

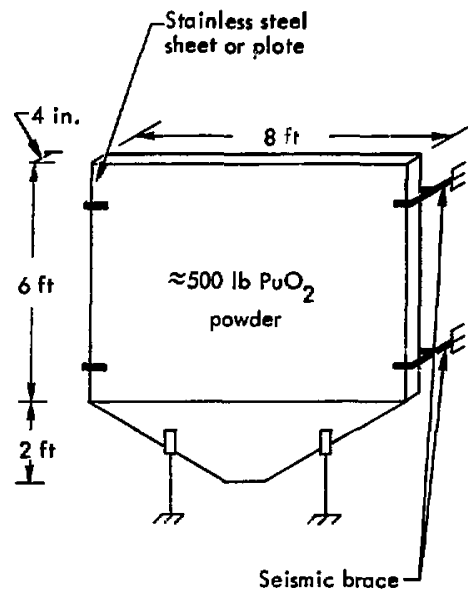

Fig. 10. Representative $\mathrm{PuO}_{2}$ storage bin. Seismic brace will prevent lateral motion and allow vertical motion for weighing.

braces $\because n$ be designed to handle seismic loads resulting from acceleration of many g's.

\section{Ventilation System and Utility Piping}

We considered the venti?ation system shown in Fig. 3 to be reasonably rejresentative of a typical system. We $\mathrm{re}^{-}$ stricted our examination to the final iEPA filter bank. A failure of the final HEPA filter could produce a large potential leak path.

Figure 11 shows a HEPA filter frame designed by ORNL-NSIC-65 guidelines. 9 These guidelines state (1) that the frame must be designed to carry a 2-psi shock loading across the bank without exceeding the elastic limit of the material, and (2) that the maximum member deflections must be limited to $0.1 \%$ of their length under a loading equivalent to 1.5 times 


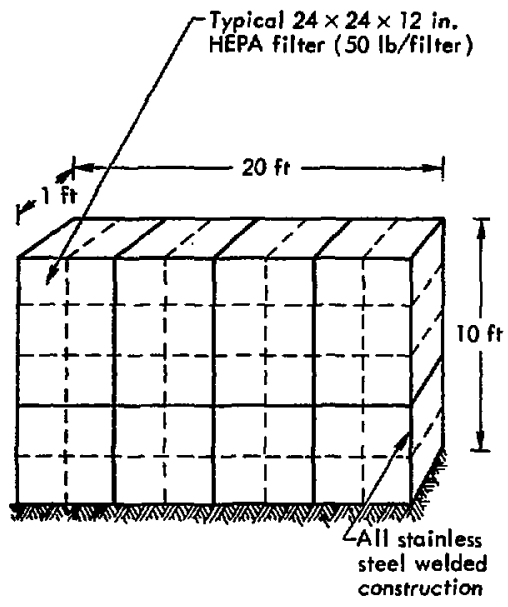

Fig. 11. Typical final HEPA filter frame.

the maximum dirty-filter pressure drop across the bank. Since these criteria are far more severe than seismic criteria, they govern the design. We judge that the structural integrity of the final HEPA filter frame is such that floor acceleration levels greater than $1 \mathrm{~g}$ are required to cause failures.

Because most designs do not consider the stack an effective part of the system, we also neglect it. The purpose of the stack is to start dispersion of the filtered air and provide it with an initial upward velocity. The worst type of failure expected would be a complete collapse of the stack, which would also seal the stack and prevent filtered air from leaving the building. Such a failure is very unlikely.

We did not perform an rxtensive struetural analysis of ventilation ducting and utility piping. Both are relatively lightweight (16 gage) and are usually sufficiently anchored to the main building structure so that any failures of the ducting or piping lines would not be the result of vibratory motions. Failure would most likely result from falling objects (concrete spalling) or excessive relative displacements between anchor points that should not occur until total building collapse.

Utility lines consist of 1/2-in. diam piping containing nonexplosive mixtures of hydrogen and nitrogen, and compressed air; 1- to 3-in. diam water lines; and 3/4-in. diam hydraulic lines. Failure of any of these lines does not itself create the potential for a radioactive release. The compressed air lines could provide a means of dispersing plutonium oxide powder only if they are located in the immediate vicinity of the powder. Ventilation ducting consists of 16 gage 18-in. diam lines. A break in the ventilation ducting could be a potential source of a small radioactive release since it is anticipated that plutonium oxide would be plated on the interior walls of the ducting upstream from the final HEPA banks.

\section{Ground Motion and Damping}

We used AEC Regulatory Guide 1.60 (Ref. 1) to define the ground-motion ingut to our model MOFFP. Guide 1.60 describes a procedure acceptable to the
NRC staff for defining response spectra for the seismic design of nuclear power plants. The guide is based on a statistical treatment of recorded ground 
accelerations and response spectra of past earthquakes. It is intended for sites underlain by either rock or soil deposits, and it covers all frequencies of interest. For unusually soft sites, modification of this procedure is required.

Guide 1.60 gives both horizontal and vertical response spectra for different values of structural damping. All are

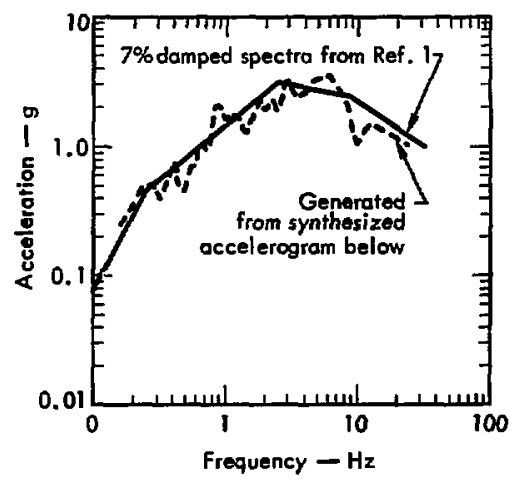

(a) Conparison of acseleration spectro

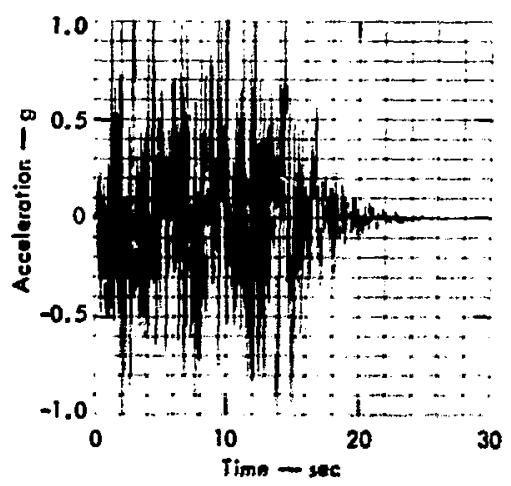

(b) Synthesized accelerogron

Fig. 12. Horizontal ground motion. normalized to a maximum horizontal ground acceleration of $1.0 \mathrm{~g}$. Once the intensity of ground motion for a site is specified in terms of maximum horizontal ground acceleration, both horizontal and vertical spectra can be defined from Guide 1.60 simply by scaling.

In addition to specifying the ground motion in terms of respunse spectra, it

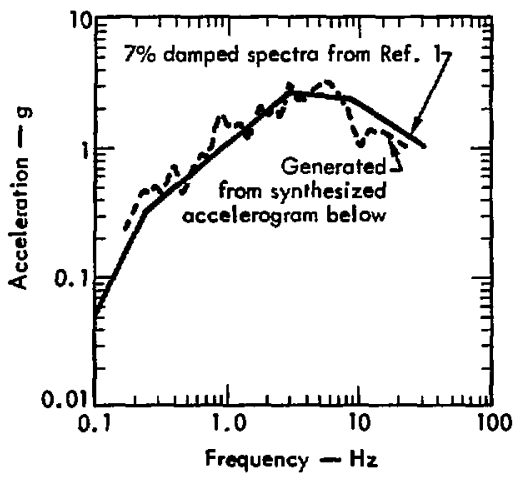

(a) Comparison of acceleration spectra

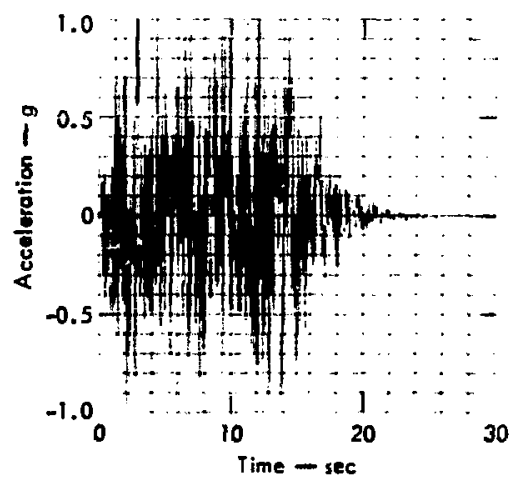

(b) Synthesizod accelerogrom

Fig. 13. " Fertical around motion. 
was necessary to synthesize accelerograms, for input to the dynamic timehistory analysis, that would reasonably rellect the frequency content of the specified spectra. We generated such accelerograms using the computer code SIMEAR. ${ }^{10}$ In developing the accelerograms, we selected a $30-$ sec record with 10 to $15 \mathrm{sec}$ of strong shaking. We believe that these parameters are representative of motions near large earthquakes. For examp!es, a magnitude 7.7 earthquake recorded at Taft, Callfornia nad a dura- tion of $\mathbf{3 0}$ sec and a duration of strong shaking of $10 \mathrm{sec}$. A magnitude 7.1 earthquake recorded in Olympia, Washington had duration parameters of $30 \mathrm{sec}$ and 13 sec. There were no recorded data for the Charleston, South Carolina earthquake (1886), but historical accounis indicate that the near epicentral durations were within the above ranges.

Figures 12 and 13 show the horizontal and vertical response spectra and synthesized accelerograms used in this study. They are normalized to a maximum

Table 1. Modified Mercalli intensity levels.

\begin{tabular}{ll}
$\begin{array}{l}\text { Modified } \\
\text { Mercalli } \\
\text { intensity } \\
\text { leval }\end{array}$ & \multicolumn{1}{c}{$\begin{array}{c}\text { Approximate intensity } \\
\text { of earthquake }\end{array}$} \\
\hline l & $\begin{array}{l}\text { Detected only by sensitive instruments. } \\
\text { II }\end{array}$ \\
Felt by a few persons at rest, especially on upper floors; \\
delicate suspended objects may swing.
\end{tabular}


horizontal ground acceleration of $1.0 \mathrm{~g}$. Figures $12(\mathrm{a})$ and $13(\mathrm{a})$ show the actual response spectra generated from the synthesized accelerograms, and the accelerograms are shown in Figs. $12(\mathrm{~b})$ and 13(b;. A comparison shows reasonable agreement over the entire frequency range of interest.

We used a $7 \%$ viscous damping value. This value is consistent with AEC Regulatory Guide 1.61 (Ref, 5), which delineates damping values acceptable for elastic dynamic analysis. The $7 \%$ value is a particularly reasonable choice for reinforced concrete structures subjected to strong ground motions. It accounts for energy dissipation and reflects bot 1 material anct structural damping for stresses less than yield. Increased damping associated with stressing members beyond yield was included in our material stressstrain characterization.

Table 1 shows estimates o: maximum horizontal ground acceleration corresponding to various intensity levels on the Mudified Mercalli intensity scale (MM). We used this table to define different intensities of ground shaking corresponding to MM's ranging from $v 11(-0.2$ g) to $X-X I I(\geq 1.0 \mathrm{~g})$.

\section{Analysis of the Main Structure of the Manufacturing Building}

We made a seismic response analysis of the main structure of the manufacturing building. We conducted both dynamic elastic and inelastic response analyses for the horizontal and vertical directions, treating both directions separately. The elastic analysis was performed with the computer program SAPIV, ${ }^{11}$ using the acceleration response-spectra ground motion directly. The inelastic analyses was performed with DRAIN2D, ${ }^{12}$ using the synthetic ground-motion accelerogram developed. An equivalent viscous damping of $7 \%$ of critical was used for all calculations.

\section{HORIZON -AL ANALYSES}

Figure 14 shows the lumped mass model used to capture the horizontal response characteristics of the building. The springs $K_{1}$ and $K_{2}$ are shear springs that represent the lateral resistance of the shear walls. The mass of the building is distributed to the roof, second floor, and first floor $\left(M_{1}, M_{2}\right.$, and $\left.M_{3}\right)$. The mass used at the roof level $\left(M_{1}\right)$ is based on the total roof weight, one-half the second-story wall weight, and the estimated weight of the equipment attached to the wall and roof. The second-story

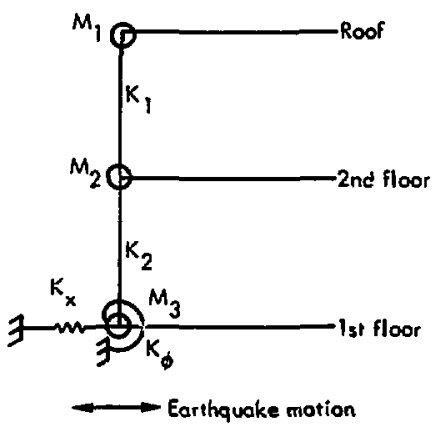

Fig. 14. Model used for horizontal response calculations. 
mass $\left(M_{2}\right)$ includes the weight of the floor, one-half the weight of both the first and second-story walls, and estimated equip-

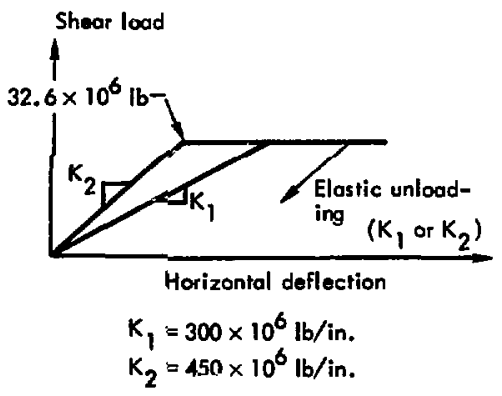

Fig. 15. S Siear resistance of walls. ment weight. At ground level, the mass: $\left(M_{3}\right)$ is based on one-half the first-story wall weights, a foundaticn mat, and the estimated equipment weight. Actual mass values used were $33,500,39,000$, and $24,000 \mathrm{lb} \cdot \sec ^{2} / \mathrm{in}$. for $M_{1}, M_{2}$, and $\mathrm{M}_{3}$, respectively.

Figure 15 shows the Iateral resistance characterization used. These values reflect the shear resistance of the reinforced concrete walls parallel to the direction of the motion. The lateral resistance of the columns was neglected. Elaatic unloading was assumed, as was a concrete ductility ratio at 2.5 .

Figure 16 defines the soil-structure spring constants used in the elastic

\begin{tabular}{|c|c|c|c|c|c|}
\hline Site & $\begin{array}{c}\text { Shear-wave } \\
\text { velocity } \\
(\mathrm{ft} / \mathrm{sec})\end{array}$ & $\begin{array}{c}\text { Soil } \\
\text { unit } \\
\text { waight } \\
\left(\mathrm{lb} / \mathrm{ft}^{3}\right)\end{array}$ & $\begin{array}{c}\text { Shear } \\
\text { modulii } \\
\left(\mathrm{lb} / \mathrm{ft}^{2}\right)\end{array}$ & $\begin{array}{c}\mathrm{K}_{x} \\
(\mathrm{lb} / \mathrm{in} .)\end{array}$ & $\begin{array}{c}\mathrm{K}_{\phi} \\
\text { (in.-lb/rad) }\end{array}$ \\
\hline Hand & 8000 & 150 & $298 \times 10^{6}$ & $1.41 \times 10^{12}$ & $25.5 \times 10^{15}$ \\
Intermediate & 2000 & 125 & $15.5 \times 10^{6}$ & $7.33 \times 10^{8}$ & $1.33 \times 10^{15}$ \\
Soft & 500 & 100 & $0.78 \times 10^{6}$ & $3.67 \times 10^{7}$ & $6.65 \times 10^{13}$ \\
\hline
\end{tabular}

$$
\begin{aligned}
& K_{x}=2(1+v) G \beta_{x} \sqrt{B L} \\
& K_{\phi}=\frac{G}{i-v} \beta_{\phi} B_{L}^{2} \\
& B=L=210 \mathrm{ft} \\
& v=0.35
\end{aligned}
$$

G = Shear modulus of ssil.

$v=$ Poiseon's ratio of soil.

$B=$ Fourdation dimention

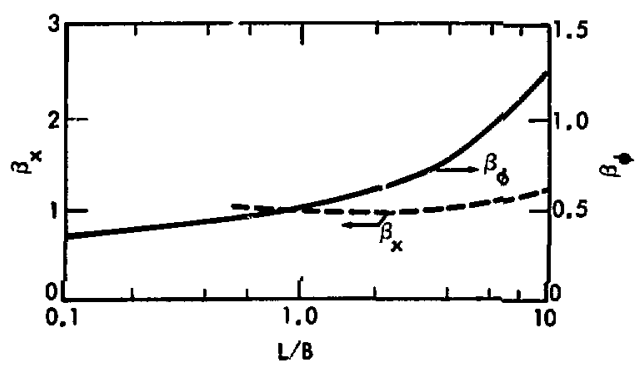
parpendicular to applied ferce. Coefficients $\beta_{x}$ and $\beta_{\phi}$ for rectangular footings

$\mathbf{L}=$ foundation dimention porollal to opplied force.

$\beta_{x_{p}} \beta_{p}=$ Funclioms of $L / B$ and are shown.

Fig. 16. Soll-structure interaction characteristics based on Ref. 11. 
analysis the springs are $k_{x}$ and $K_{\phi}$ in Fig. 14). These values were developed from the criteria given in Ref. 13. These soil-structure interaction paraneters were included because of the gussibility of founding future MOFFP's on hard, intermediate, or soft sites. The soil springs reflect shear-wave velocities of 8000,2000 and 500 fps, respectively.

Figure 17 summarizes the results of the horizontal elastic response analysis. It shows the lowest timree fundamental mode shapes for each of the three sites and the corresponding fundamental periods. Values for the lowest fundamental period varied from 0.10 to 0.34 sec. The base shear and deformations are given for a 1-g peak horizontal ground-motion level. For the inelestic analysis, the maximum lateral load capacity of eacin wall was determined to be $32.6 \times 10^{6} \mathrm{lb}$. This value is based on a 360 -psi ultimate shearstress capacity of the walls with web reinforcement. We ascumed the horizontal

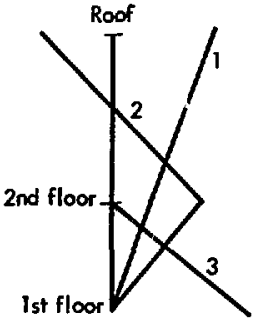

$$
\begin{aligned}
& T_{1}=0.096 \mathrm{sec} \\
& T_{2}=0.047 \mathrm{sec} \\
& T_{3}=0.0001 \mathrm{sec}
\end{aligned}
$$

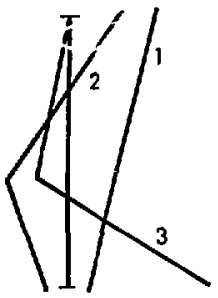

$$
\begin{aligned}
& T_{1}=0.116 \mathrm{sec} \\
& T_{2}=0.046 \mathrm{sec} \\
& T_{3}=0.027 \mathrm{sec}
\end{aligned}
$$

\begin{tabular}{|c|c|c|}
\hline Hard site & Intermediate site & Soft site \\
\hline $\begin{aligned} v_{\text {base }} & =55 \times 10^{6} \mathrm{lb} \\
\Delta_{\text {roof }} & =0.24 \mathrm{in.} \\
\Delta_{2 \text { d floor }} & =0.12 \mathrm{in.} \\
\Delta_{\text {lst floor }} & =0 \mathrm{in} .\end{aligned}$ & $\begin{aligned} v_{\text {bose }} & =69.7 \times 10^{6} \mathrm{lb} \\
\Delta_{\text {roof }} & =0.41 \mathrm{in} . \\
\Delta_{2 \text { nd floor }} & =0.27 \mathrm{in.} \\
\Delta_{\text {lst floor }} & =0.11 \mathrm{in.}\end{aligned}$ & $\begin{aligned} v_{\text {base }} & =90 \times 10^{6} \mathrm{lb} \\
\Delta_{\text {roof }} & =0.39 \mathrm{in} . \\
\Delta_{2 \text { nd floor }} & =0.35 \mathrm{in} . \\
\Delta_{1 \text { st floor }} & =0.32 \mathrm{in} .\end{aligned}$ \\
\hline \multicolumn{3}{|c|}{$1=$ lst mode } \\
\hline \multicolumn{3}{|c|}{2 = 2nd mode } \\
\hline \multicolumn{3}{|c|}{$3=3 \mathrm{rd}$ mode } \\
\hline
\end{tabular}

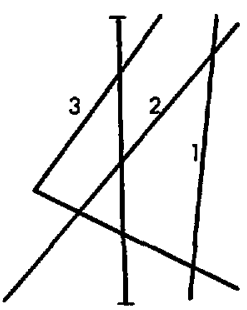

$$
\begin{aligned}
& T_{1}=0.341 \mathrm{sec} \\
& T_{2}=0.077 \mathrm{sec} \\
& T_{3}=0.034 \mathrm{sec}
\end{aligned}
$$

Fig. 17. Results for horizontal elastic analysis (based on spectra normalized to $1 \mathrm{~g}$ ). 
Table 2. Results from inelastic dynamic time-history analysis - (horizontal).

\begin{tabular}{ccccc}
\hline $\begin{array}{c}\text { Acceleration } \\
\text { level } \\
\text { (g) }\end{array}$ & $\begin{array}{c}\text { Maximum } \\
\text { 2nd floor } \\
\text { displacement } \\
\text { (in.) }\end{array}$ & $\begin{array}{c}\text { Maximum } \\
\text { roof } \\
\text { displacement } \\
\text { (in.) }\end{array}$ & $\begin{array}{c}\text { Wall shear } \\
\text { bottom } \\
\text { panel } \\
\text { (psi) }\end{array}$ & $\begin{array}{c}\text { Wall shear } \\
\text { top panel } \\
\text { (psi) }\end{array}$ \\
\hline 0.50 & 0.068 & 0.152 & 334 yield & 201 \\
0.60 & 0.086 & 0.163 & 360 & 266 \\
0.70 & $0.110_{1}$ & $0.189_{2}$ & $360_{1}$ & $284_{3}$ \\
0.75 & $0.127_{1}$ & $0.206_{2}$ & $360_{1}$ & $292_{3}$ yield \\
0.80 & $>3.0_{3}$ & $>9.0_{3}$ & $360_{3}$ & $360_{3}$ \\
\hline
\end{tabular}

Initial yielding occurs at 2.5 sec.

\begin{tabular}{cc} 
Subscript & $\begin{array}{c}\text { Time of } \max \text { value } \\
\text { (sec) }\end{array}$ \\
\hline 1 & 2.5 \\
2 & 4.0 \\
3 & $12-12.5$
\end{tabular}

temperature and shrinkage reinforcement also acted as web reinforcement. Neglecting the web reinforcement, yields a 190-psi ultimate value.

Table 2 summarizes the results from the horizontal inelastic-response analysis. Note that these calculations do not include soil-structure interaction effects. The building model was assumed fixed at ground level. Table 2 shows maximum floor and roof displacements and maximum shear wall stresses for different levels of ground motion. The results show that the lower shear walls exhibit inelastic deformations between $0.5-$ nad $0.6-\mathrm{g}$ accelerations and greater. At approximately 0.75 to $0.8 \mathrm{~g}$, the upper shear wall also becomes inelastic, and the total structure collapses.

\section{VERTICAL ANAL YSES}

Figure 18 shows the model used to characterize the vertical load-carrying resistance of the building. It represent s

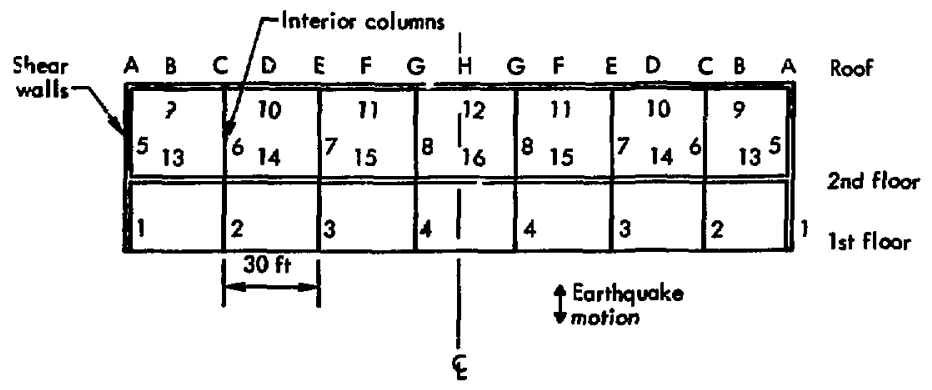

(30-it slice between column line)

Fig. 18. Model tsed for vertical response calculation. 


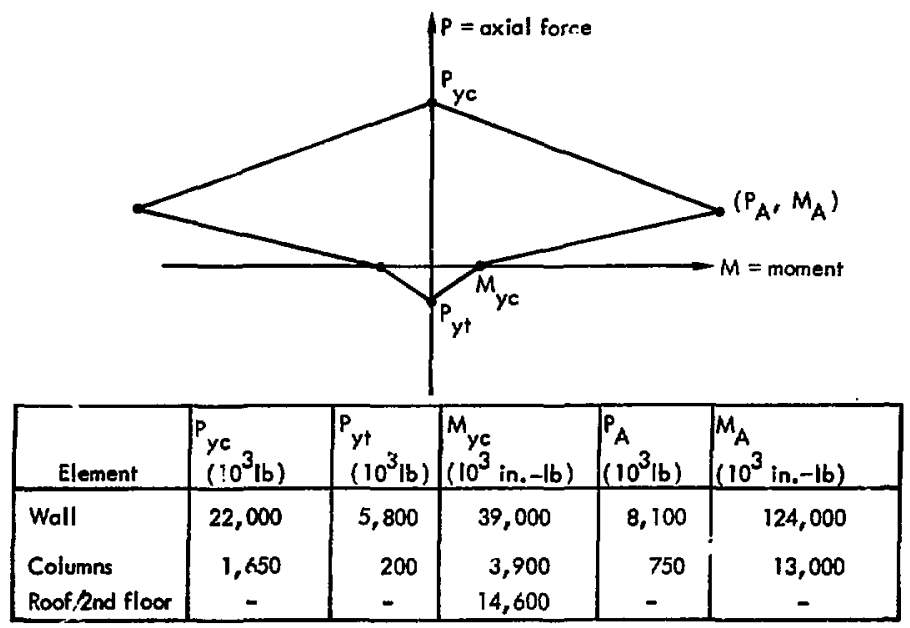

Fig. 19. Yield interaction diagram for the reinforced concrete walls, columns, roof, and walls.

the second floor and roof slabs as beams spanning between columns at interior bays and spanning to the walls at the exterior bays. The columns and walls were treated as beam-column elements.

Moments of inertia $w \in r e$ based on gross-concrete sections. We used values of 27,700 and 175,000 in. ${ }^{4}$ for the columns and floor/roof/wall sections, and crosssectional aress of 576 and 6480 in. $^{2}$, respectively. Member-yield criteria were developed using ultimate-strength design concepts and a review of experimental data of failure of reinforced concrete

Table 3. Results of elastic vertical analysis.

\begin{tabular}{|c|c|c|c|c|}
\hline \multirow[b]{2}{*}{ Line $^{a}$} & \multicolumn{2}{|c|}{ Static loads } & \multicolumn{2}{|c|}{$1-\mathrm{g}$ earthquake } \\
\hline & $\begin{array}{l}\text { Max roof } \\
\text { deflection } \\
\text { (in.) }\end{array}$ & $\begin{array}{l}\text { Max 2nd floor } \\
\text { deflection } \\
\text { (in.) }\end{array}$ & $\begin{array}{l}\text { Max roof } \\
\text { deflection } \\
\text { (in.) }\end{array}$ & $\begin{array}{l}\text { Max 2nd floor } \\
\text { deflection } \\
\text { (in.) }\end{array}$ \\
\hline A & - & - & 0.008 & 0.003 \\
\hline $\mathbf{B}$ & 0.193 & 0.133 & 0.476 & 0.023 \\
\hline $\mathbf{C}$ & 0.154 & 0.088 & 0.186 & 0.085 \\
\hline $\mathbf{D}$ & 0.232 & 0.165 & 0.211 & 0.194 \\
\hline $\mathbf{E}$ & 0.154 & 0.088 & 0.160 & 0.085 \\
\hline $\mathbf{F}$ & 0.226 & 0.160 & 0.350 & 0.209 \\
\hline $\mathbf{G}$ & 0.153 & 0.088 & 0.232 & 0.117 \\
\hline $\mathbf{H}$ & 0.227 & 0.161 & 0.433 & 0.348 \\
\hline
\end{tabular}

asee Fig. 18. 
Table 4. Results from elastic vertical analysis $-1-g$ earthquake.

\begin{tabular}{|c|c|c|c|c|c|c|}
\hline $\begin{array}{l}\text { Roof/ } \\
\text { 2nd floor a } \\
\text { memsers }\end{array}$ & $\begin{array}{c}\text { Max } \\
\text { moment } \\
\left(10^{7} \text { in. }-1 b\right)\end{array}$ & $\begin{array}{c}\text { Max shear } \\
\left(10^{5} \text { lb }\right)\end{array}$ & $\begin{array}{c}\text { Wall / } \\
\text { column } \\
\text { members }\end{array}$ & $\begin{array}{c}\text { Max } \\
\left(10^{7} \text { in }-1 b\right)\end{array}$ & $\begin{array}{c}\text { Max shear } \\
\left(10^{5} \mathrm{lb}\right)\end{array}$ & $\begin{array}{c}\text { Max axial } \\
\text { force } \\
\left(10^{5} \mathrm{lb}\right)\end{array}$ \\
\hline 9 & 2.71 & 2.31 & 1 & 0.30 & 35.6 & 2.47 \\
\hline 10 & 1.22 & 2.22 & 2 & 0.12 & 11.6 & 6.18 \\
\hline 11 & 1.51 & 1.61 & 3 & 0.06 & 5.85 & 6.09 \\
\hline 12 & 1.77 & 1.83 & 4 & 0.22 & 1.39 & 8.42 \\
\hline 13 & 0.25 & 0.16 & 5 & 1.44 & 0.55 & $2.4 i$ \\
\hline 14 & 0.17 & 0.07 & 6 & 0.16 & 0.07 & 4.83 \\
\hline 15 & 1.05 & 1.13 & 7 & 0.10 & 0.05 & 3.76 \\
\hline 16 & 1.77 & 1.50 & 8 & 0.13 & 0.05 & 5.56 \\
\hline
\end{tabular}

a See Fig. 18.

Table 5. Results from elastic vertical analysis - static only.

\begin{tabular}{|c|c|c|c|c|c|c|}
\hline $\begin{array}{l}\text { Roof/ } \\
\text { 2nd floor } \\
\text { members }\end{array}$ & $\begin{array}{c}\text { Max } \\
\text { moment } \\
\left(10^{7} \text { in. }-1 b\right)\end{array}$ & $\begin{array}{c}\text { Max shear } \\
\left(10^{5} \text { lb }\right)\end{array}$ & $\begin{array}{c}\text { Wall/ } \\
\text { colurnn } \\
\text { membersa }\end{array}$ & $\begin{array}{c}\text { Max } \\
\text { moment } \\
\left(10^{7} \text { in. } r 1 b\right)\end{array}$ & $\underset{\left(10^{5}\right.}{\operatorname{Max})}$ & $\begin{array}{c}\text { Max axial } \\
\text { force } \\
\left(1.0^{5} \mathrm{lb}\right)\end{array}$ \\
\hline 9 & 0,82 & 1.63 & 1 & 0.33 & 0.21 & 3.12 \\
\hline 10 & 0.88 & 1.59 & 2 & - & - & 6.33 \\
\hline 11 & 0.8 .7 & 1.58 & 3 & - & - & 6.32 \\
\hline 12 & 0.86 & 1.58 & 4 & - & - & 1.53 \\
\hline 13 & 0.83 & 1.59 & 5 & 0.66 & 0.32 & 3.19 \\
\hline 14 & 0.88 & 1.59 & 6 & - & - & 3.18 \\
\hline 15 & 0.88 & 1.59 & 7 & - & - & 3.16 \\
\hline 16 & 0.86 & 1.59 & 8 & - & - & - \\
\hline
\end{tabular}

${ }^{\text {a }}$ See Fig. 18.

Table 6. Results inelastic vertical analysis.

\begin{tabular}{|c|c|c|c|c|c|c|c|c|}
\hline$\underset{\text { line }^{\mathrm{a}}}{\text { Column }}$ & $\begin{array}{c}\frac{0.40 \mathrm{~g}+}{\text { Max Foo }} \\
\text { defi. } \\
\text { (in.) }\end{array}$ & $\begin{array}{l}\frac{\text { tatic load }}{\text { Max } 2 n d} \\
\text { foor defl. } \\
\text { (in.) }\end{array}$ & $\begin{array}{l}\frac{0.50 g+}{\text { Max roof }} \\
\text { defl. } \\
\text { (in.) }\end{array}$ & $\begin{array}{l}\text { static load } \\
\text { Max } \\
\text { floor defl. } \\
\text { (in.) }\end{array}$ & 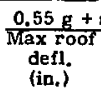 & $\begin{array}{c}\text { static load } \\
\text { Max 2nd } \\
\text { floor deff. } \\
\text { (in.) }\end{array}$ & $\begin{array}{l}\frac{0.57 \mathrm{~g} \div}{\text { Max roof }} \\
\text { defl. } \\
\text { (in.) }\end{array}$ & $\begin{array}{l}\frac{\text { iatic load }}{\text { Max 2nd }} \\
\text { floor defl. } \\
\text { (in.) }\end{array}$ \\
\hline A & 0.011, & $0.006_{2}$ & 0.012 & $0.007_{2}$ & $0.012_{2}$ & $0.007_{2}$ & $0.010_{2}$ & $0.006_{2}$ \\
\hline B & $0.226_{2}$ & $0.203_{3}$ & $0.385_{2}$ & $0.219_{2}^{2}$ & $0.411_{2}^{2}$ & $0.227_{2}^{2}$ & $0.326 \frac{6}{2}$ & $0.200_{2}^{2}$ \\
\hline C & $0.239_{1}$ & $0.133_{1}$ & $0.260_{1}$ & $0.145_{1}$ & $0.270_{1}$ & $0.159_{1}$ & $0.215_{2}$ & $0.124_{2}$ \\
\hline D & $0.371_{1}$ & $0.27 \mathrm{f}_{1}$ & $0.420_{3}$ & $0.304_{1}$ & $0.447_{3}$ & $0.325_{1}$ & $0.305 b 2$ & $0.215_{2}$ \\
\hline $\mathbf{E}$ & $0.247_{1}$ & $0.14 t_{1}$ & $0.271_{1}$ & $0.152_{1}^{2}$ & $0.280_{1}$ & $0 .: 58_{1}$ & $0.179_{2}$ & $0.105_{2}$ \\
\hline$F$ & $0.379_{4}$ & $0.258_{1}$ & $0.437_{3}$ & $0.283_{2}$ & $0.468_{3}$ & $0.298_{1}$ & $0.295 \frac{b}{2}$ & $0.233^{2}$ \\
\hline G & $0.249_{1}$ & $0.135_{1}$ & $0.272_{1}$ & $0.148_{1}$ & $0.288_{1}$ & $0.156_{1}^{2}$ & $0.168_{2}$ & $0.101_{2}$ \\
\hline H & $0.398_{2}$ & 0.251 & $0.469_{3}$ & $0.288_{2}$ & $0.535_{3}$ & $0.291_{2}$ & $0.283_{2}^{b}$ & $0.198_{2}$ \\
\hline
\end{tabular}

"See Fig. 18.

${ }^{b}$ At 10 sec. these deflections are greater than $10 \mathrm{in}$. Subscript Time of max deflection (sec)

$\begin{array}{lc}1 & 5.02 \\ 2 & 8.71-9.32 \\ 3 & 12.12 \\ 4 & 14.39\end{array}$


members. Figure 19 is the vield interaction diagram used for the different structural elements. Assumed reinforcement details are shown in Fig. 7 .

The mass of the building was distributed uniformly at the roof and foor levels. We used values consistent with a $30-\mathrm{ft}$ slice of the building, assuming a 125-psf live load and a 225-psf dead load. The live load is typical of hrave manufacturinn facilities.

Tables 3 through 5 summarize the results from the vertical elastic response analysis. Table 3 gives the maximum rouf and floor level deflections resulting from s.atic (live and dead) loads and a $\mathrm{I}-\mathrm{g}$ vertical earthquake ground motion. Tables 4 and 5 give the maximum member forces for the same two loading conditions. The first five periods of vibration were salculated as $0.129,0.120,0.117,0.111$, and 0.107 sec.

Table 6 and Fig. 20 summarize the results from the inelastic vertical response analysis. Table 6 gives the miximum roof and seconc-floor level deflections for increasing levels of earthquake ground motion varying from 0.4 to $0.57 \mathrm{~g}$. Figure 20 shows pictorially the location of plastic hinge formations. Both Table 6 and Fig. 20 also show the time of occurrence of the maximum values.

Fig. 20. Results of inelastic vertical analysis.

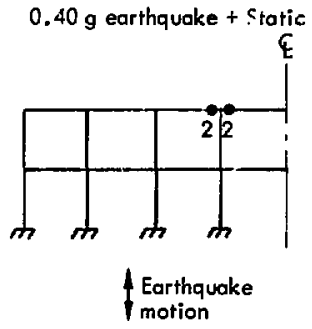

$0.50 \mathrm{~g}$ earthquake + Static

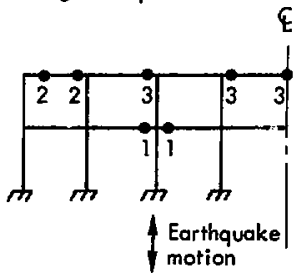

$0.55 \mathrm{~g}$ earthquake + Static

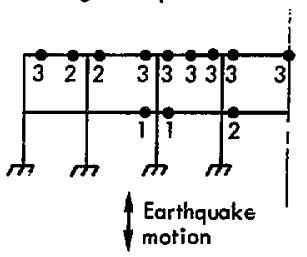

- = plastic hinge formation

\begin{tabular}{c|c} 
Symbol & $\begin{array}{l}\text { Time of max } \\
\text { plastic hinge } \\
\text { formation (sec) }\end{array}$ \\
\hline 1 & 5.02 \\
2 & $8.95-9.33$ \\
3 & $14.5-14.8$
\end{tabular}

\section{Results and Discussion}

HORIZONTAL RESPONSE RESULTS

The inelastic horizontal-response calculation indicated no inelastic behavior or yielding for horizontal ground-motion levels below $0.5-g$ maximum acceleration. For gruund-motion levels of 0.6 to $0.75 \mathrm{~g}$, response excursions into the inelastic 
range occur at the bottom shear-wall panel (ground level to second floor level). For ground-motion level greater than $0.8 \mathrm{~g}$, both the bottom and top shear-wall panels have sufficient excursions into the inelastic regime to cause large displacements that lead to total collapse of the structure.

Initial yielding (i.e., shear stresses greater than $360 \mathrm{psi}$ ) always occurred early (at about $2.5 \mathrm{sec}$ ). For ground motion of 0.6 to $0.75 \mathrm{~g}$, the maximum roof displacement followed at about $4.0 \mathrm{sec}$. At $0.9 \mathrm{~g}$ and greater, deflection of $3 \mathrm{in}$. and more were calculated at 12 to $12.5 \mathrm{sec}$.

The most valuable result we obtained from the elastic horizontal-response calculations was the establishment of trends in response variutions as a function of possible soil-structure interaction effects. The soil springs used reflect site characteristics that are reasonably representative of hard, intermediate, and soft sites. The results indicate considerable variation in response characteriztics for these different sites.

1) The fundament al period varied more than $300 \%$ going from the hard site to the solt (0.10 to $0.34 \mathrm{sec})$.

2) Mode shapes also showed considerable differences.

3) Both intermediate and soft site anal$y$ sis results indicated considerable rigid body translation.

4) The total roof displacement for both the intermediate and soft site cases was the same and was $66 \%$ greater than in hard site cases.

5) Helative displacement for the soft site calculations was only $30 \%$ of that for the hard site. The intermediate case showed $25 \%$ greater relative displacement than the hard site.
6) Base shears increased $65 \%$ from the hard to soft site cases. This increase results from better coupling between the structural system with the ground motion.

Our elastic analysis with soil-structure interaction suggest that an inelastic analysis with soil-structure characterization would show total collapse of the building at a lower level of ground motion intensity. We feel that a reasonable estimate for total collapse of the building with soilstructure interaction effects included is in the $0.5-$ to $0.6-g$ range.

\section{VERTICAL IRESPONSE RESULTS}

The elastic response analysis of the building indicates that the first five periods of vibration are very close $(0.129$ to 0.107 sec). Maximum roof and second floor deflections for a $1-\mathrm{g}$ earthquake with static dead and live loads included are 0.23 and 0.16 in., respectively. For a $0.4-\mathrm{g}$ vertical ground motion, values are 0.19 and $0.14 \mathrm{in.}$

Table 6 and Fig. 20 summarize the results from the vertical analysis. Below 0.4-g ground-motion levels, no yielding occurs. At the 0.4-g ground-motion level, yielding or plastic hinges are formed only at the innermost column line in the roof slab. At $0.5 \mathrm{~g}$, most of the roof slab has yielded, as well as some at the second floor level. At the $0.55-\mathrm{g}$ level, yielding is even more extensive. Above $0.55 \mathrm{~g}$, the extent of yielding is sufficient to lead to a total collapse of the structure. At the $0.57 \mathrm{~g}$ level, most of the plastic hinges occur at 5 sec; at 10- to 11-sec deflections at the midspan of both the roof and second floor slabs all exceed 10 in. 
DISCUSSION

Results in icate that below $0.6-\mathrm{g}$ maximum horizontal ground motion, the main building will show no appreciable damage. At $0.8 \mathrm{~g}$ and greater, the total lateral resisting capacity of the building will be exceeded and the building will collapse. These conclusions are based on the inelastic response analysis, which neglects possible soil-structure effects.

If the MOFFP should be founded on intermediate or soft sites, an extrapolation from the elastic response analysis (which did account for soil-structure interaction) shows that total building collapse from lateral motions would occur in the 0.5- to 0.6-g range.

For vertical motions, results indicate that roof slab damage (e.g., concrete cracking, and spalling) will occur at approximately 0.4-g maximum ground acceleration. At $0.5-$ to $0.55-\mathrm{g}$ levels, the floor slab and most of the roof slab exhibit plastic deformation. At groundmotion levels greater than $0.55 \mathrm{~g}$, vertical motion will cause total collapse of the building.
Our examination of the primary confinement barriers in the building (glove boxes, gloved barriers, $\mathrm{PuO}_{2}$ storage bins, and ventilation system) showed that they appear to have structural integrity to resist vibratory notions with peak floor accelerations greater than $1 \mathrm{~g}$. We would anticipate failures of the ventilation ducting and utility piping only in conjunction with major failure of the main manufacturing building structure.

It is important to remember that the response characteristics of the majority of most future MOFFP's will reflect designs primarily influenced by tornado criteria, as did our own MOFFP characterization. Such a design will have response characteristics consistent with stiff brittle structures having little reserve energy capacity. These structures typically will have to meet seismic criteria of 0.1 to $0.2 \mathrm{~g}$. With minimum structural modification (e.g., additional reinforcing steel in walls and slabs and perhaps closer column spacing), the building could be made capable of carrying ground motion levels exceeding the $1 \mathrm{~g} g$ intensity level.

\section{Acknowledgments}

The authors acknowledge the assistance and encouragement of V. N. Karpenko, Leader; and C. E. Walter, Deputy Leader; Nuciear Test Engineering Division, Mechanical Engineering Department, Lawrence Livermore Laboratory. We would like to particularly thank Dr. R. L. Gotchy, U.S. NRC, Office of Standards Development, for providing guidance and support throughout this study. His comments and suggestions have been most helpful.

We also appreciate the time spent by Mr. Kevin Barry and his associates at the Ralph M. Parsons Company, Dr. Roy Nilson of the Exxon Nuclear Company. and Lyle Schwendiman and his associates of Battelle Northwest for their aid in defining model MOFFP's. 


\section{References}

1. U, S. AEC Regulatory Guide 1.60, "Design Response Spectra for Nuclear P'ower Plants," Rev. 1 (December 1973).

2. U.S. AEC Regulatory Guide 1.61, "Damping Values for Seismic Tesign of Nuclear Power Plants" (October 1973).

3. The Safety of Nuclear Power Reactors and Related Facilities, U.S. AEC Rept. WASH-1250 (July 1973).

4. License Application, Recycle Fuels Plant, Westinghouse Nuclear Fuel Division, Pittsburgh, PA (July, 1973).

5. J. M. Selby, et al. , Considerations in the Assessment of the Consequences of Effluents from Mixed Oxide Fuel Fabrication Plants, Battelle Pacific Northwest Laboratories, Rept, BNWL-1697, UC41 (June 1973).

6. U.S. AEC Regulatory Guide 1.76, "Design Basis Tornado for Nuclear Power Plants" (April 1974).

7. ANSI A58.1-1972, "Building Code Requirements for Minimum Design Loads in Buildings and Other Structures, "American National Standards Institute, Inc.

8. Building Code Requiements for Reinforced Concrete, Amrican Concrete Institute, Pub. 318-71 (1971).

9. C. A. Burchsted and A. B. Fuller, Design, Construction, and Testing HighEfficiency Air Filtration Systems for Nuclear Applications, ORNL-NSIC-65 (1970).

10. M. Watabe, "SIMEAR Generation of Simulated Earthquake, " National Information Service; - Earthquake Engineering University of California, Berkeley, Document No. 09-573 (December 1972).

11. K. J. Bathe, E. L. Wilson and F. E. Peterson, SAPIV Structure Analysis Program for Static and Dynamic Response of Linear Systems, Earthquake Engineering Research Center, University of California, Berkeley, Rept. EERC 73-11 (1973).

12. A. Kanaan and G. H. Powell, General Purpose Computer Program for Inelastic Dynamic Response of Plane Structures, Earthquake Engineering Research Center, University of California, Berkeley, Rept. EERC 73-6 (1973).

13. R. V. Whitman and F.E. Richart, Jr., "Design Procedures for Dynamically Loaded Foundations," Soil Mechanics and Foundations Division (Nov. 1967), p. 169193.

$\mathrm{RAC} / \mathrm{md} / \mathrm{lmc}$ 